\title{
Changes in the lipid inclusion/Sertoli cell cytoplasm area ratio during the cycle of the human seminiferous epithelium
}

\author{
R. Paniagua*, M. C. Rodríguez*, M. Nistal†, B. Fraile* and P. Amat $\ddagger$
}

* Department of Cytology and Histology, Faculty of Biology, University of Salamanca, E-37008

Salamanca; † Department of Morphology, School of Medicine, Autonomous University, E-28029

Madrid; and $\ddagger$ Department of Electron Microscopy, University Clinical Hospital, E-37007

Salamanca, Spain

\begin{abstract}
Summary. The area occupied by Sertoli cell lipid inclusions-electron-lucent lipid vacuoles (LLV) and electron-dense lipid droplets (DLD) - at each stage of the cycle of the seminiferous epithelium was measured on electron micrographs in young adults and elderly men, and expressed as the ratio "area occupied by lipid inclusions/area occupied by the Sertoli cell cytoplasm". For LLV this ratio increased from stage I to stage III, and decreased from stage IV to stage VI in young adults. These results suggest that the development of LLV is synchronized with the spermatogenic process: the residual bodies released in stages I and II are phagocytized by Sertoli cells and transformed into LLV; the amounts of LLV decrease in the subsequent stages of the cycle and increase again when new residual bodies appear. In elderly men the ratio LLV/ Sertoli cell cytoplasm was $1.9-2.9$ times higher than in young adults at each stage of the cycle. This increase may be related to the increased germ-cell degeneration observed in ageing testes, DLD were less abundant than LLV and the DLD/Sertoli cell cytoplasm ratio did not undergo cyclic changes in young adults or elderly men.
\end{abstract}

\section{Introduction}

Sertoli cells have been reported to exhibit cyclic changes in follicle-stimulating hormone binding and action (Parvinen et al., 1980), as well as in the secretion of androgen-binding protein (Ritzén et al., 1982), and plasminogen activator (Fritz et al., 1981). In addition, a number of light- and electron-microscopic studies have shown variations in the form and content of Sertoli cell organelles and inclusions during the cycle of the seminiferous epithelium in a variety of mammalian species (Fawcett, 1975). Recently, the cyclic accumulation and depletion of Sertoli cell lipid inclusions during the rat spermatogenic cycle, suggested by various reports (Lacy, 1960; Niemi \& Kormano, 1965; Posalaki et al., 1968; Kerr \& de Kretser, 1975), have been corroborated by morphometric studies (Kerr et al., 1984).

Human Sertoli cells display numerous droplets and lipid vacuoles, the latter belonging to the group of phagolysosomes (Holstein \& Roosen-Runge, 1981; Schulze, 1984). Although no evidence has been presented for a correlation between the lipid content of Sertoli cells and the cycle of the seminiferous epithelium in man, according to the quantity and composition of lipid inclusions, four functional stages of the human Sertoli cell have been distinguished (Schulze, 1974).

The aim of the present report was to describe the variations observed in the surface area occupied by lipids in the human Sertoli cell during the cycle of the seminiferous epithelium and the possible relationship between these changes and the spermatogenic process. 


\section{Materials and Methods}

Testicular biopsies were obtained about $2 \mathrm{~h}$ after death from both testes of 30 adult men who died in traffic accidents (19 men) or from other accidents ( $6 \mathrm{men})$ and had not suffered from testicular, endocrine or related diseases. The men were classified into two groups according to their age: 15 young adults (from 24 to 42 years of age), and 15 elderly men (from 61 to 89 years of age).

Small fragments $\left(1 \mathrm{~mm}^{3}\right)$ of each testicular specimen were fixed in $3 \%$ cacodylate-buffered glutaraldehyde, postfixed in $1 \%$ veronal-buffered osmium tetroxide, and embedded in araldite. Semi-thin sections were stained with toluidine blue. Ultrathin sections were double stained with uranyl acetate and lead citrate and examined with a Philips-300 electron microscope.

For the quantitative study, 20 electron microscopic fields $\left(4200 \mu \mathrm{mm}^{2}\right)$ from each of the 6 stages of the cycle were selected at random in each testis, photographed at $\times 2000$, and examined at a final magnification of $\times 10000$. On each electron micrograph the areas occupied by the two types (electron lucent and electron dense) of lipid inclusions and by the Sertoli cell cytoplasm were measured with a semi-automatic image analyser (Kontron, Zeiss, Oberkochen, FRG). The results were expressed as the ratio "area occupied by lipid inclusions/area occupied by the Sertoli cell cytoplasm". For each stage of the cycle the average values per testis were calculated. From these values the means and standard errors of the mean were obtained. The significance of differences between means was evaluated by analysis of variance.

In the young adults and elderly men, only seminiferous tubules showing qualitatively normal (complete) spermatogenesis were photographed (Figs 1-6). In elderly men, the tubules selected were similar to those of young adults except for more abundant lipid inclusions, a lower number of spermatids, and a slightly reduced tubular diameter; many of the tubules not selected showed different degrees of maturation arrest of spermatogenesis at the level of spermatids, spermatocytes or spermatogonia, a thickened tunica propria, a reduced tubular diameter, and larger amounts of lipid inclusions than the tubules with complete spermatogenesis. The reason for excluding measurements of the tubules with maturation arrest was the absence of a recognizable cycle of the seminiferous epithelium.

\section{Results}

Two types of lipid inclusions could be distinguished in the cytoplasm of most Sertoli cells (Figs 1-6): (1) small electron-dense lipid droplets (DLD), and (2) large electron-lucent lipid vacuoles (LLV) (Fig. 3). The latter were the most abundant (Figs $1 \& 2,4 \& 5$ ) and, in some Sertoli cells principally in elderly men they tended to coalesce, forming large accumulations (Figs $5 \& 6$ ). Residual bodies and secondary lysosomes suggesting intermediate stages between residual bodies and LLV were seen (Fig. 3), mainly in stages VI, I and II of the cycle.

The changes throughout the cycle in the LLV/Sertoli cell cytoplasm ratio are shown in Table 1. Differences between samples from the same testis were lower than between testes. In young adults this ratio increased significantly from stage I to stage III, and then declined significantly from stage IV to stage VI. In elderly men the LLV/Sertoli cell cytoplasm ratio was higher than in young adults in all stages of the cycle; this ratio increased significantly from stage II to stage III, thereafter declining significantly from stage IV to stage VI, and remained constant throughout stages VI-II.

Fig. 1. Seminiferous tubule from a young adult man (27 years of age) showing complete spermatogenesis and a moderate amount of lipid inclusions (li). Toluidine blue, $\times 450$.

Fig. 2. Stage III of the cycle in a 26-year-old man. Pachytene spermatocytes (P) and Sa spermatids (Sa) can be seen. The Sertoli cells (Se) show numerous lipid inclusions (Li). $\times 3000$.

Fig. 3. Part of a Sertoli cell in another seminiferous tubule (stage II) from the same man as in Fig. 2, showing two types of lipid inclusions: small electron-dense lipid droplets (DLD) and larger electron-lucent lipid vacuoles (LLV). A secondary lysosome (asterisk) suggesting an intermediate stage between a residual body and an electron-lucent lipid vacuole is seen. $\times 14000$. 

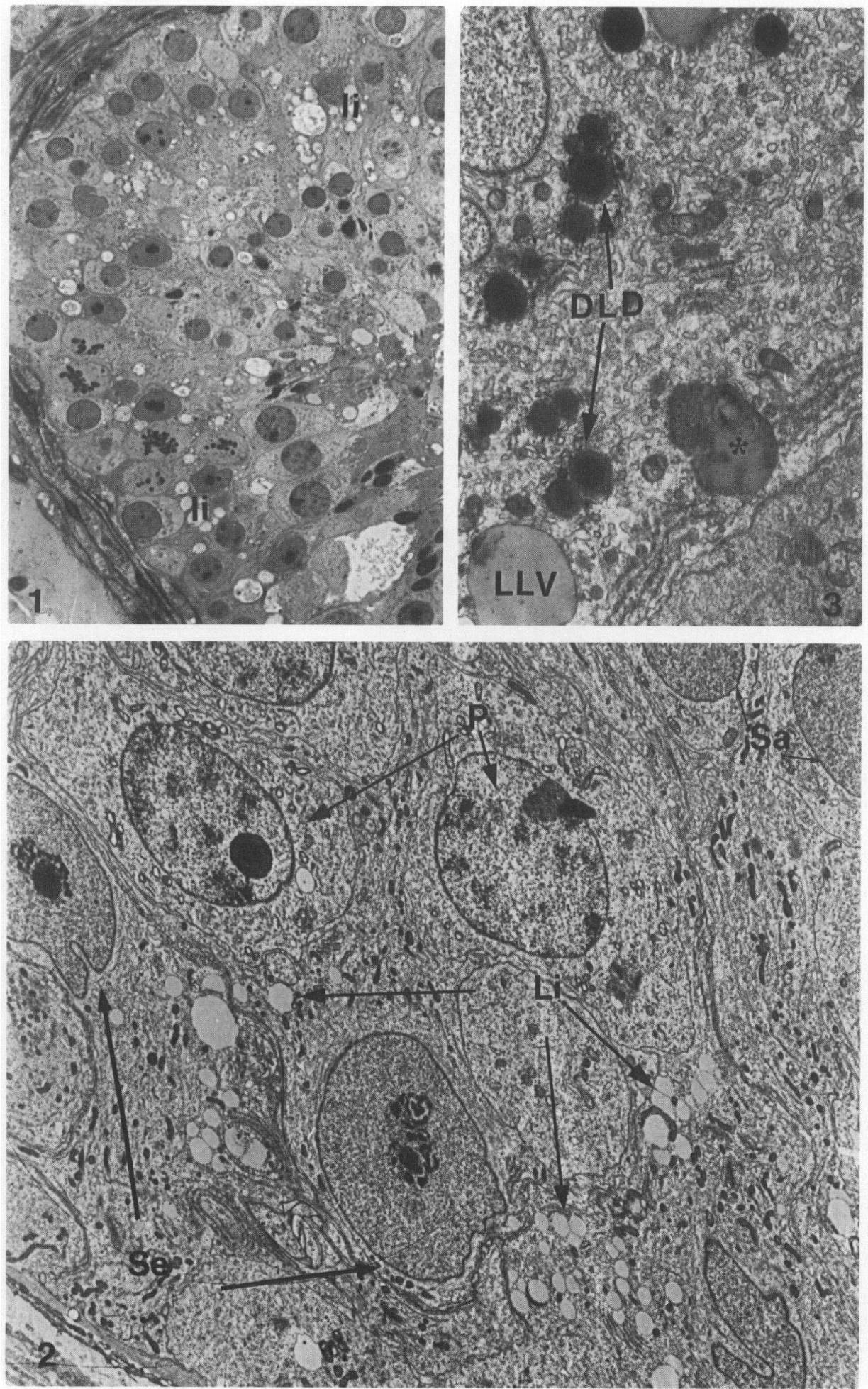

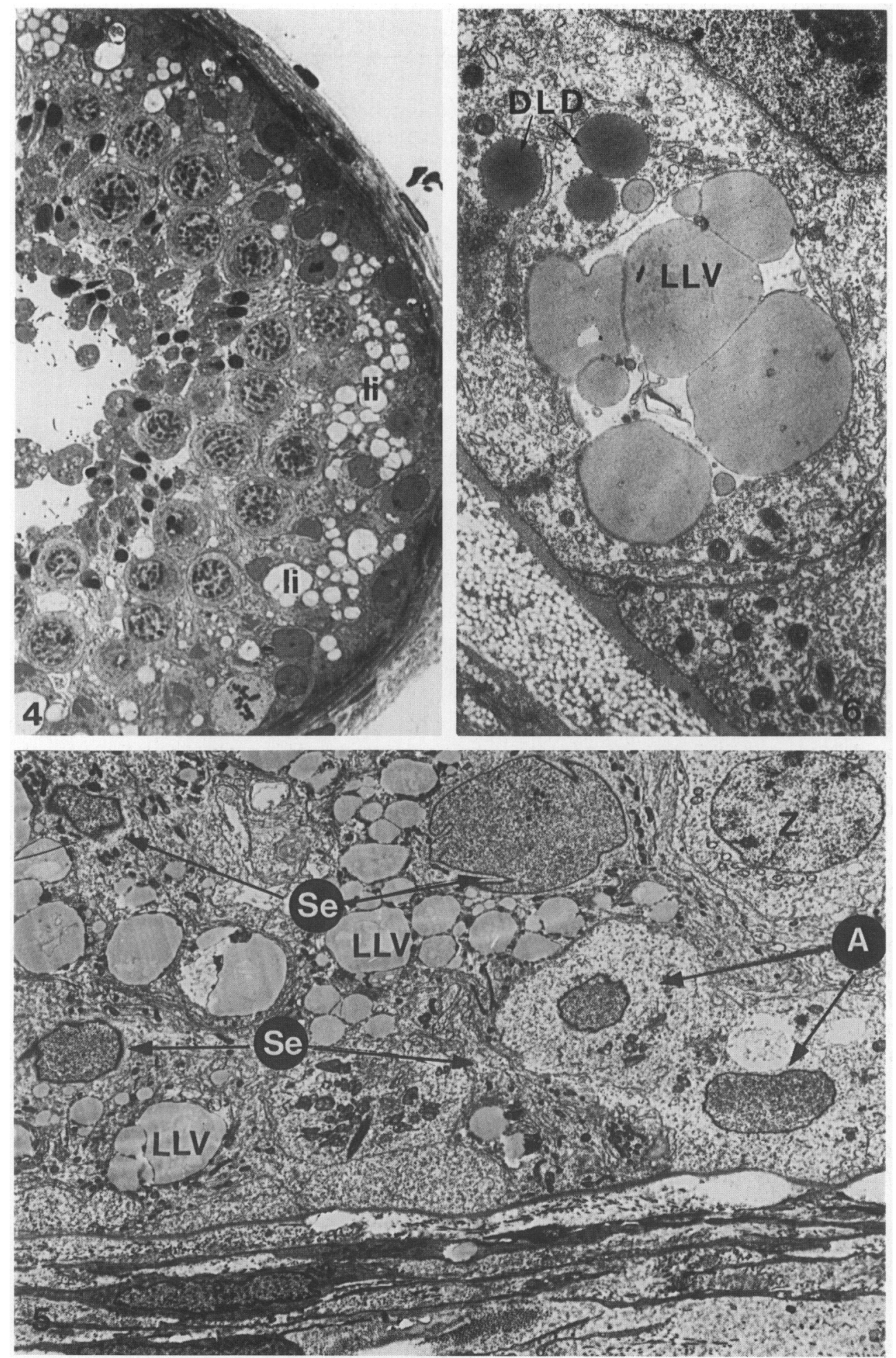
Table 1. Ratio of area occupied by lipid inclusions/area occupied by the Sertoli cell cytoplasm $\left(\times 10^{4}\right)$ during the 6 stages of the cycle of the human seminiferous epithelium in young adults and elderly men

\begin{tabular}{|c|c|c|c|c|c|c|}
\hline \multirow[b]{2}{*}{ Lipid inclusions } & \multicolumn{6}{|c|}{ Stages of the cycle } \\
\hline & I & II & III & IV & $\mathrm{v}$ & VI \\
\hline \multicolumn{6}{|l|}{ Electron-lucent } & \\
\hline $\begin{array}{l}\text { Young adults } \\
\text { Elderly men }\end{array}$ & $\begin{array}{l}236 \pm 11^{\mathrm{a}} \\
684 \pm 37^{\mathrm{cd}}\end{array}$ & $\begin{array}{l}365 \pm 15^{\mathrm{b}} \\
672 \pm 38^{\mathrm{cd}}\end{array}$ & $\begin{array}{c}612 \pm 25^{\mathrm{c}} \\
1227 \pm 72^{\mathrm{ef}}\end{array}$ & $\begin{array}{r}543 \pm 21^{\mathrm{c}} \\
1062 \pm 59^{\mathrm{c}}\end{array}$ & $\begin{array}{l}395 \pm 19^{\mathrm{b}} \\
849 \pm 47^{\mathrm{de}}\end{array}$ & $\begin{array}{l}318 \pm 15^{\text {ab }} \\
661 \pm 36^{\text {cd }}\end{array}$ \\
\hline \multicolumn{7}{|c|}{$\begin{array}{l}\text { Electron-dense } \\
\text { lipid droplets (DDL) }\end{array}$} \\
\hline $\begin{array}{l}\text { Young adults } \\
\text { Elderly men }\end{array}$ & $\begin{array}{l}43 \pm 3^{\mathrm{g}} \\
85 \pm 7^{\mathrm{h}}\end{array}$ & $\begin{array}{l}50 \pm 4^{8} \\
71 \pm 6^{\mathrm{b}}\end{array}$ & $\begin{array}{l}40 \pm 3^{\mathrm{g}} \\
76 \pm 6^{\mathrm{h}}\end{array}$ & $\begin{array}{l}45 \pm 4^{8} \\
80 \pm 8^{h}\end{array}$ & $\begin{array}{l}41 \pm 3^{g} \\
85 \pm 8^{h}\end{array}$ & $\begin{array}{l}47 \pm 4^{\mathrm{g}} \\
75 \pm 7^{\mathrm{h}}\end{array}$ \\
\hline
\end{tabular}

Values are expressed as means \pm s.e.m.

Values with different superscript letters are significantly different $(P<0 \cdot 05)$.

The DLD/Sertoli cell cytoplasm ratio throughout the 6 stages of the cycle in young adults is shown in Table 1. Although the values in elderly men differed significantly $(P<0.05)$ from those in young adults in each stage of the cycle, the DLD/Sertoli cell cytoplasm ratio did not undergo any significant changes during the cycle in young or elderly men.

\section{Discussion}

The two types of Sertoli cell lipids presumably have a different function. The most abundant lipids (LLV) are contained in electron-lucent vacuoles which are defined by a membrane; they have been considered as telolysosomes derived from both phagocytosed germ cells and residual bodies released from spermatids during spermiogenesis (Schulze, 1984). This notion arises from the observation that the number of lipid vacuoles increases considerably following iatrogenic damage to the germinal epithelium causing germ cell degeneration (Schulze, 1984), whereas lipid vacuoles are inconspicuous in seminiferous tubules with germ cell hypoplasia, such as in Del Castillo's syndrome (Chemes et al., 1979; de Kretser et al., 1981), Klinfelter's syndrome (Nistal et al., 1982), cryptorchidism (Schulze et al., 1976), and hypogonadotrophic hypogonadism (de Kretser, 1968). The small electron-dense lipids (DDL) are not surrounded by a membrane and correspond to the usual lipid droplets found in most cell types; if the Sertoli cell synthesizes steroid hormones, as has been postulated (Lacy, 1962; Fawcett, 1975), these lipids might represent steroid precursors.

The results of this study show that the LLV/Sertoli cell cytoplasm ratio undergoes cyclic changes synchronized with the cycle of the seminiferous epithelium, reaching a peak at stage III. This agrees with the origin attributed to these vacuoles (telolysosomes) and suggests that the

Fig. 4. Seminiferous tubule from an elderly man ( 77 years of age) showing complete spermatogenesis and numerous lipid inclusions (li). Toluidine blue, $\times 450$.

Fig. 5. Stage IV of the cycle in a 74-year-old man. One binucleate A spermatogonium (A), and one zygotene spermatocyte $(Z)$ can be seen, together with Sertoli cells (Se) filled by electronlucent lipid vacuoles $($ LLV). $\times 3000$.

Fig. 6. Sertoli cell from the same testis as in Fig. 5, showing coalescence of electron-lucent lipid vacuoles (LLV). DLD: electron-dense lipid droplets. $\times 21000$. 
residual bodies, formed during the elongation and complete differentiation of spermatids at stages VI to I of the cycle (Clermont, 1963; Holstein \& Roosen-Runge, 1981) and phagocytosed by Sertoli cells (Fawcett, 1975; Russell, 1980; Holstein \& Roosen-Runge, 1981), are transformed into LLV during stages I through III. These lipids decrease in the subsequent stages of the cycle and increase again when new residual bodies appear. These cyclic changes in lipid content are similar to those reported in the rat seminiferous tubules which show a maximum lipid content during stages IX-XIV of their cycle (Kerr et al., 1984), following the release of spermatid residual bodies and the increase in secondary lysosomes in the Sertoli cells (Morales et al., 1986).

The increase in LLV beginning at stage I in humans also agrees with the loss of late prophaseanaphase II spermatocytes reported in the human testis, even in young adults (Johnson et al, 1983). This loss occurs at stage VI when pachytene spermatocytes give rise to round spermatids; about $43 \%$ of these spermatocytes undergo degeneration (Johnson et al., 1983) and are probably phagocytosed by Sertoli cells and transformed into LLV. Abundant redidual bodies have been observed at this stage.

The LLV/Sertoli cell cytoplasm ratio in ageing testes undergoes cyclic changes similar to those observed in young adults, although this ratio was about $1.9-2.1$ times that measured in young adult testes at each stage of the cycle except for stage $I$ in which this ratio was 2.9 times higher than in stage $I$ in young adults. An augmented Sertoli-cell lipid content in ageing human seminiferous tubules has been reported previously (Lynch \& Scott, 1950; Paniagua et al., 1985) and may be attributed to the elevated number of degenerating germ cells observed in ageing testes (Paniagua $e t$ al., 1987). The disproportionate increase in lipids observed at stage I in elderly men might be due to an increased loss of spermatocytes at stage VI of the cycle (unpublished observations).

In contrast with LLV no cyclic changes in the DLD/Sertoli cell cytoplasm ratio were observed. If these lipid are used for steroid biosynthesis (Lacy, 1962), such synthesis seems to be unrelated to the stage of the cycle. DLD are also increased in elderly men. This has two possible explanations: (1) DLD are derived from lipids contained in the LLV, and therefore an increase in LLV would be associated with an increase in DLD; and (2) steroid biosynthesis is decreased in ageing Sertoli cells, leading to an accumulation of unused precursors.

This work was supported by grants from the "Comisión Aesora de Investigación Científica y Técnica" and the "Excma Diputación Provincial de Salamanca", Spain.

\section{References}

Chemes, H.E., Dym, M., Fawcett, D.W., Javadpour, N. \& Sherins, R.J. (1979) Patho-physiological observations of Sertoli cells in patients with germinal aplasia or severe germ cell depletion. Ultrastructural findings and hormone levels. Biol. Reprod. 17, $108-123$.

Clermont, Y. (1963) The cycle of the seminiferous epithelium in man. Am. J. Anat. 112, 35-51.

de Kretser, D.M. (1968) The fine structure of the immature human testis in hypogonadotropic hypogonadism. Virchows Arch. A. Pathol. Anat. Histol. 1, 283-296.

de Kretser, D.M., Kerr, J.B. \& Paulsen, C.A. (1981) Evaluation of the ultrastructural changes in the human Sertoli cells in testicular disorders and the relationship of the changes to the levels of serum FSH. Int. J. Androl. 4, 129-144.

Fawcett, D.W. (1975) Ultrastructure and function of the
Sertoli cell. In Handbook of Physiology: Male Reproductive System, pp. 21-55. Eds D. W. Hamilton \& R. O. Greep. Williams \& Wilkins, Baltimore.

Fritz, I.B., Parvinen, M., Karmally, K. \& Lacroix, M. (1981) Preferential production of testicular plasminogen activator by Sertoli cells in discrete positions (Stages VII and VIII) of the seminiferous tubule. Ann. N.Y. Acad. Sci. 383, 447-448.

Holstein, A.F. \& Roosen-Runge, E.C. (1981) Atlas of Human Spermatogenesis. Grosse-Verlag, Berlin.

Johnson, L., Petty, C. \& Neaves, W.B. (1983) Further quantification of human spermatogenesis: germ cell loss during postprophase of meiosis and its relationship to daily sperm production. Biol. Reprod. 29, 207-215.

Kerr, J.B. \& de Kretser, D.M. (1975) Cyclic variations in Sertoli cell lipid content throughout the spermatogenic cycle in the rat. $J$. Reprod. Fert. 43, 1-8. 
Kerr, J.B., Mayberry, R.A. \& Irby, D.C. (1984) Morphometric studies on lipid inclusions in Sertoli cells during the spermatogenic cycle in the rat. Cell Tiss. Res. 236, 609-709.

Lacy, D. (1960) Light and electron microscopy and its use in the study of factors influencing spermatogenesis in the rat. J. roy. Microsc. Soc. 79, 209-225.

Lacy, D. (1962) Certain aspects of testis structure and function. Br. med. Bull. 18, 205-208.

Lynch, K.M. \& Scott, W.W. (1950) The lipid content of the Leydig cell and the Sertoli cell in the human testis as related to age, benign hypertrophy and prostatic cancer. J. Urol. 64, 767-776.

Morales, C., Clermont, Y. \& Nadler, N.J. (1986) Cyclic endocytic activity and kinetics of lysosomes in Sertoli cells of the rat: a morphometric analysis. Biol. Reprod. 34, 207-218.

Niemi, M. \& Kormano, M. (1965) Cyclical changes in and significance of lipids and acid phosphatase activity in the seminiferous tubules of the rat testis. $Z$. Zellforsch. mikrosk. Anat. 73, 89-106.

Nistal, M., Paniagua, R., Abaurrea, M.A. \& Santamaría, L. (1982) Hyperplasia and the immature appearance of Sertoli cells in primary testicular disorders. Hum. Pathol. 13, 3-12.

Paniagua, R., Amat, P., Nistal, M. \& Martín, A. (1985) Ultrastructural changes in Sertoli cells in ageing humans. Int. J. Androl. 8, 295-312.
Paniagua, R., Nistal, M., Amat, P., Rodriguez, M.C. \& Martín, A. (1987) Seminiferous tubule involution in elderly men. Biol. Reprod. (in press).

Parvinen, M., Marana, R., Robertson, D.M., Hansson, V. \& Ritzen, E.M. (1980) Functional cycle of rat Sertoli cells: differential binding and action of folliclestimulating hormone at various stages of the spermatogenic cycle. In Testicular Development, Structure and Function, pp. 425-432. Eds A. Steinberger \& E. Steinberger. Raven Press, New York.

Posalaki, Z., Szabo, D., Bacsi, E. \& Okros, I. (1968) Hydrolytic enzymes during spermatogenesis in rat. An electron microscopic and histochemical study. $J$. Histochem. Cytochem. 16, 249-262.

Ritzén, E.M., Boitani, C., Parvinen, M., French, F.S. \& Feldman, M. (1982) Stage dependent secretion of ABP by rat seminiferous tubules. Molec. cell. Endocrinol. 25, 25-33.

Russell, L.D. (1980) Sertoli-germ cell interrelations: a review. Gamete Res. 3, 179-202.

Schulze, C. (1974) On the morphology of the human Sertoli cell. Cell Tiss. Res. 153, 339-355.

Schulze, C. (1984) Sertoli cells and Leydig cells in man. Adv. Anat. Embryol. Cell Biol. 88, 1-104.

Schulze, C., Holstein, A.F., Schirren, C. \& Körner, F. (1976) On the morphology of the human Sertoli cells under normal conditions and in patients with impaired fertility. Andrologia 8, 167-178.

Received 5 November 1986 